\title{
Do Remittances Affect Politics in Bangladesh?
}

\begin{abstract}
:
This paper examines how remittances contribute to the democratisation process in Bangladesh. The endogeneity issue between remittances and democracy is tackled by employing the Structural VAR (SVAR) approach. It is found that while remittances respond to innovations in the macro-political variables, remittances also have important impact on these variables. Our results build a synergy between two opposing findings in the politics literature where on one hand remittances flows stabilise autocracies, while on the other hand they foster the prospect for democratisation. In particular, we demonstrate that a shock in remittances flows will have a negative but transitory impact on democracy. Initially there will be a bout of autocratic episodes which will be eventually eliminated and democracy will be restored to its original level in three to five years. However, using an alternative measure for democracy with the aid of principal-component analysis, we find that after the fifth year following a shock in remittances flows, a small but positive permanent effect on democracy is observable that do not revert to zero at end of the ten period horizon.
\end{abstract}

Keywords: Remittances, Democratisation, Bangladesh.

JEL Classifications: O10, O15, F22 


\section{Introduction}

Remittances sent by migrant workers to their families have become important sources of funds for many developing countries. The growth rate of remittances worldwide has been quite remarkable in the last two decades. Analyses of World Bank data show that during 2007 and 2008, the growth rate in remittances was 15 percent $^{1}$.

Studies devoted to economic consequences of remittances find a number of benefits to its recipients. For example, remittances are credited with the reduction of poverty, alleviation of credit constraint, and improvements in the educational and health outcomes of the recipient households (see; Adams \& Page, 2005; Cox-Edwards \& Ureta, 2003; Frank \& Hummer, 2002; Gupta at al., 2009; Hanson \& Woodruff, 2003; Hildebrant \& Mckenzie, 2005; Page \& Plaza, 2006; Quartey \& Blankson, 2004). Remittances are instrumental in generating savings and accumulation of productive assets by removing investment constraints (see; Arun \& Ulku, 2011; Chiodi at al., 2012). Remittances are compensatory flows generating countercyclical behaviour that enables transfer recipients to smooth their consumption and minimise its volatility (see; Chami at al., 2008, Chami et al., 2005; Combes \& Ebeke, 2011; Kurosaki, 2006; Mishra, 2005; Sayan, 2006). Countercyclical remittances can work as automatic output stabilisers and reduce income volatility (see; Chami et al., 2008, 2009; Yang \& Choi, 2007). The inflow of remittances does, however, pose several development challenges, specifically in terms of controversial effects on economic growth (see; Chami et al., 2003; World Bank, 2006), and their capacity to appreciate the real exchange rate, causing a Dutch disease effect (see;

\footnotetext{
${ }^{1}$ Ratha et al. (2009). Barajas et al. (2009) and Chami et al. (2008) have reported that during 2007, remittances through official channels were $\$ 300$ billion in addition to unknown transfers through unofficial channels, which are estimated to be about 40 percent of flows through the official channels.
} 
Amuedo-Dorantes \& Pozo, 2004; Acosta et al., 2007; Chami et al., 2008; Hassan \& Holmes, 2013; Montiel, 1999).

The political consequences of remittances in the recipient countries is relatively understudied (Meseguer \& Burgess, 2014). The increase in worldwide emigration due to the advent of globalisation may cause changes to the dynamics of the political scenario in the outmigration countries for variety of reasons, one of which could be remittance receipts. Only recently in the political science literature has the question of how out-migration influences political change, and in particular democratisation gained some momentum (Kapur 2010; Moses 2011; Pfutze, 2012).

Are the impact of receiving remittances on political behaviour significant in recipient countries? There are several scholarly work which show that emigrants although geographically separated from their home country, engage in its politics (Levitt 1998; Kapur 2010) and they do so exerting the so called "voice" after "exit" (Careja \& Emmenegger, 2012; Meseguer \& Burgess, 2014). These studies usually analyse the impact of receiving remittances on political behaviour of the migrant household or the consequences of remittances on electoral outcomes. In a recent study it is found that remittances can advance democratisation by undermining the capacity of autocratic regimes to mobilise electoral support through the delivery of goods and services (Escriba-Folch et al., 2015). Similarly, the non-taxability of remittances income can also foster a more competitive elections by making it hard for an incumbent government's ability to maintain political patronage systems (Pfutze, 2012).

One may also get the impression that remittances flows being an international transfer analogous to foreign aid or non-tax revenue can on the other hand sustain authoritarian regimes that reduce the need for taxation and enhance the capacity of current regimes to purchase political support or quell dissents (Morrison, 2009). Likewise, Ahmed (2012) demonstrates that 
foreign aid and remittance inflows in conjunction can sustain autocracies by empowering government to survive longer. The effect of the combination of foreign aid and remittances on the government survival depends on the fact that these inflows of money are unearned foreign income that can be exploited to attain perverse objectives of a government. Although the nature of remittances flow is different to that of foreign aid or oil rents because remittances are small household-to-household private income transfers, emigration can still alter political behaviour of the migrant family in such a way that those who receive remittances are less likely to depend on the state and more on the family to satisfy their needs (Hiskey, 2008:170). In addition, because remittances are countercyclical flows they can insulate recipient households from domestic economic shocks which might lower dissatisfaction with the incumbent regime (Regan and Frank, 2014:5-8).

It was recently noted by Abdih et al. (2012) that remittances can affect the quality of governance. The authors showed that remittances can lower civic engagement by playing a buffer role between government and citizens, and deteriorate the quality of institutions and governance in receiving countries by reducing the incentives for citizens to monitor and hold their government accountable. Families receiving remittances may be oblivious to the quality of governance because they are better insulated, as a result of income received from overseas, from the bad decisions made by their governments.

This paper explores remittance receiving patterns in Bangladesh and their impacts on relevant macro-political variables. In particular, we trace how workers' remittances are linked to home country's GDP and democratisation process. The focus on Bangladesh is well justified because it receives one of the highest volumes of yearly remittances in the world and given its long history of emigration and the curious developmental problems and prospects, we believe that Bangladesh, is an ideal laboratory to investigate whether the democratisation process responds to the flow of foreign income transfers in a dynamic context. In departure from 
previous literature, we specifically model and analyse the time series behaviour of democracy and remittances to measure how the former responses to a shock in the latter.

While one can easily argue that inward remittances flows may affect the level of GDP through alleviating liquidity constraints on investment and the level democratisation by altering electoral process, causality may also run in other direction. Aggregate remittances inflow may be influenced by macroeconomic and political conditions. For example, a negative shock in home country's GDP may attract more remittances because migrants' utility is increasing in their own consumption as well as in their families' consumptions. Likewise, a steady and functioning democracy in the home country may signal that migrants view the political and economic environment favourable where they can trust to send their money.

In sum, while macroeconomic and political conditions are likely to impact the level of remittances flowing to Bangladesh, remittances may also affect the level of GDP or the process of democratisation. To get a broader and more complete understanding of remittances and the macro-political economy, we use a structural time series methodology that accounts for the endogeneity resulting from this reverse causality. In this way, we can explore how the macropolitical variables affects remittances and how remittances, in turn, affect the macro-political economy. To our knowledge, this is the first such exercise measuring the impact of remittance on democratisation in Bangladesh adopting a structural time series approach to analyse the macro-political impact of remittances.

The rest of the paper is as follows: Section 2 discusses the dynamics of political process at the state level in Bangladesh since independence and section 3 provides a description of remittances received and its growth in Bangladesh. Section 4 discusses the data and the methodology adopted in this paper. Section 5 discusses the results and concludes.

\section{Political Dynamics in Bangladesh}


The cultural and political history of Bangladesh is unique: with its Muslim majority population, it once was a part of the undivided Indian sub-continent, located in the greater area of Bengal. This region was later divided into the eastern wing of Pakistan after the 1947 partition, but eventually became an independent nation in 1971 after a bloody separatist war with Pakistan in 1971. After independence Bangladesh drafted a progressive constitution in 1972 institutionalising parliamentary democracy as the form of government and enshrining secularism as a guiding principle. Awami League under the leadership of Sheikh Mujibur Rahman, the undisputed leader of the independence movement, won an overwhelming victory in the first national parliamentary election held in March 1973, winning 291 out of 300 seats with $73 \%$ of votes although the ruling party had received accusation of using strong-arm tactics to ensure lopsided victory (see; Weiss, 2014).

The first elected government of Bangladesh struggled to reconstruct the economy and society after the war and turned increasingly politically authoritarian and economically nationalistic (see; Lewis, 2011). The process culminated in passing a amendment of constitution with brute majority in January 1975 that established a one-party rule, changed form of government from parliamentary to presidential, severely curtailed press and political freedom and avowed launching of a socialist economy(see; Lewis, 2014; Weiss, 2014). Sheikh Mujibur Rahman was assassinated in August, 1975 and after a brief period of interregnum Bangladesh went through nearly 15 years of intermittent military rule and presidential government under two army generals, first Ziaur Rahman (1976 -1981) and then Hussain Muhammad Ershad (1982-1990).

During this period some political rights and press freedom were restored but they remained significantly restricted. Several national and local elections took place but their fairness and democratic credibility are questioned by political experts. Although secularism as a principle of the constitution was gradually undermined, the two regimes also set Bangladesh 
on path to economic and trade liberalisation. Also it is during this period that the foundation of the two pillars of the rapid growth in foreign exchange earnings of Bangladesh, remittance income from workers emigration and export of garments and apparels, were laid.

Bangladesh made a huge leap in democracy and political freedom in the early 90's when the unelected and unpopular president H.M Ershad gave up power and the first free, fair and competitive national election was held in 1991. Parliamentary democracy was restored along with more political and press freedom (see; Lewis, 2011). In the 1991 election, Bangladesh Nationaist Party (BNP), the party established by Ziaur Rahman, won largest number of seats and formed government. Since then three more elections, widely deemed to be fair, have taken place in 1996, 2001 and in 2008. In all these elections the immediate incumbent party lost power and the main opposition party won, forming new government. But beyond this turnover of power, democracy in Bangladesh made little progress. During the last two decades Bangladesh politics was plagued with widespread corruption, unrest and violence while patronclient relationship has become ubiquitous. The democratic recidivism reached a nadir in 2013 when hundreds of lives were lost in violence and the January, 2014 election returned incumbents to power without significant political and voter participation ${ }^{2}$.

\section{Remittances in Bangladesh}

In 1976 the Bangladesh government with the aid of active Middle East policy began exporting cheap and abundant Bangladeshi labour migrants to Middle Eastern countries to fuel their demand for construction workers. This trend later continued to other parts in East and Southeast Asia. Bangladesh is now among the top ten remittance-receiving (measured in terms of current US dollars) and manpower-exporting countries in the world (World Bank, 2011).

\footnotetext{
${ }^{2}$ http://www.hrw.org/news/2014/04/29/bangladesh-elections-scarred-violence
} 


\section{[Insert Figure 1]}

\section{[Insert Figure 2]}

Remittances constitute the most important external financial flow in the Bangladesh economy compared to foreign aid and foreign direct investments (FDI). Figure 1 plots the external flow of personal remittances receipts during the period 1976-2012. Beginning with a modest amount of US\$49 million in 1976, remittance flows reached US\$10.8 billion in 2010, an approximately two hundred-fold increase during this period. Figure 2 presents the growth in remittances from 1976-2012. The red curve shows the moving average of remittances growth and looking at which it can be seen that growth in remittances stabilised during the 1990s with marginal increase over time till 2010 after which a falling trend can be observed.

\section{Data}

To answer our research question, our empirical method integrates GDP, democracy and remittances in a system framework. While the measurement of GDP and remittances are relatively less debatable, as a measure of democracy the indicator of electoral rights, we use the Freedom House index, also known as Gastil index (See; Gastil 1982-83 and subsequent issues). The Freedom House concept of electoral rights uses the following basic definition: "Political rights are rights to participate meaningfully in the political process. In a democracy this means the right of all adults to vote and compete for public office, and for elected representatives to have a decisive vote on public policies" (Gastil 1986-87, p. 7). Freedom House applied the concept of electoral rights on a subjective basis to classify countries annually into seven categories based on two indicators-political rights and civil liberty ${ }^{3}$ that are measured on a one-to-seven scale, with one representing the highest degree of freedom and

\footnotetext{
3 "civil liberties are rights to free expression, to organize or demonstrate, as well as rights to a degree of autonomy such as is provided by freedom of religion, education, travel, and other personal rights" (Gastil 1986-87, p. 7).
} 
seven the lowest. The combined average of countries ratings for political rights and for civil determines the level of freedom, aka, democracy with a score one representing the highest level and a score seven the lowest. The original ranking from one to seven was converted here to a scale from zero to one, where zero corresponds to the fewest rights (Freedom House's rank seven) and one to the most rights (Freedom Houses's rank one). See Figure 3 for the evolution of political rights and civil liberties in Bangladesh from 1973 to 2012. We use two measures of democracies in this paper. The first approach which is the combined averages for political rights and civil liberties, is taken from Freedom House's Freedom in the World 1972-2014. In the second approach we use the principal component analysis between political rights and civil liberties and obtain the highest principal component as an alternative measure of democracy. These two indices are termed as democracy 1 and democracy 2 respectively, and grouped together in Figure 4. Having two measures of democracy allow us to check for the robustness of our empirical model. The rest of the data used in the paper - remittances in current USD and real GDP - is obtained from World Development Indicators of the World Bank.

\section{[Insert Figure 3]}

[Insert Figure 4]

\section{Methodology}

A major challenge common to most macro-political studies revolves around the observation that macroeconomic time series are endogenous. We have noted this in Section 1, where we posited, for example, that remittances may affect democratisation process by lowering the level of civic engagement and dependency on the state for its recipients or by diminishing state's capacity to buy electoral support. Yet, democracy may, in turn, also influence how much is remitted by individual migrants because stable democratic conditions may signal that migrants view the political-economic environment favourable and, as such, determine aggregate 
remittance inflows. To account for these endogeneties, our empirical methodology is based on Structural Vector Autoregression (SVAR) approach. Although vector autoregression (VAR) model was originally developed to study monetary policy transmission mechanism in the economy, the SVAR model which is based on VAR is a useful methodology to examine structural shocks in multivariate time series models which can also be employed to study the macro-political time series data (Brandt \& Freeman, 2009). SVAR approach therefore is a useful tool to examine structural shocks to Bangladesh's real GDP, democracy index and remittances flow over the period 1973 - 2012. The usefulness of the SVAR approach is that it addresses the endogeneity problem because this methodology treats all variables in the structural model as endogenous. In other words, this approach takes into account that GDP, democracy and remittances can influence each other in the system. A crucial issue in the estimation of structural model is the identification of the empirical model, but SVAR models take another approach to achieve identification by focusing on the role of shocks for the dynamics of the model by using economic theory in analysing simultaneous interaction of variables (see; Aslanidi, 2007).

The SVAR methodology is specified in the following primitive form is as follows:

$$
\mathrm{A}_{t}=\alpha+\sum_{i=1}^{P} B_{i} Z_{t-i}+u_{t}
$$

Where $Z_{t}$ is a $(n \times 1)$ vector of stationary endogenous variables, $A$ and $B_{i}$ are $(n \times n)$ matrices of structural parameters and $u_{t}$ is a $(n \times 1)$ vector of structural innovation which is orthogonal. The reduced form SVAR of Eq. (1) can be written as:

$$
Z_{t}=\mathrm{A}^{-1} \alpha+\sum_{i=1}^{P} \mathrm{~A}^{-1} B_{i} Z_{t-i}+\mathrm{A}^{-1} u_{t}
$$

Which is equivalently written as:

$$
Z_{t}=\Phi+\sum_{i=1}^{P} \Theta_{i} Z_{t-i}+\varepsilon_{t}
$$


The solution to the SVAR system is given by the following equation (see; Gianni and Giannini, 1997):

$$
\mathrm{A} u_{t}=B \varepsilon_{t}
$$

The SVAR system in Eq. (3) relates the $u_{t}$ and the underlying innovations or shocks $\varepsilon_{t}$. The A matrix relates to the covariance matrix of contemporaneous relations in endogenous variables, and the B matrix relates the SVAR to residuals of structural innovations. These relations are contemporaneous restrictions on the structural parameters of A and B matrices. The identifying restrictions of the A covariance matrix can be recursive or non-recursive. We use non-recursive identifying restrictions which is discussed later.

Our analysis is based on impulse-response functions (IRFs) of the SVAR estimations. The IRFs describes the reaction of one variable in the system to the innovations in another variable in the system, while holding all other shocks at zero. That is, IRFs provide information on the direction of the response as in whether the variable in question increases or decreases in response to a shock to another variable in the system. It is unlikely that the actual variancecovariance matrix of errors will be diagonal. Hence, to isolate shocks to one of the VAR errors, the methodology requires that identification is obtained by structural factorisation, i.e., imposing zero restrictions on the A covariance matrix with the main diagonal normalised to $1 \mathrm{~s}$. This non-recursive procedure allows to add any theoretically based restrictions on the covariance matrix A as long as SVAR is identified. The general rule is to have $\mathrm{k}(\mathrm{k}+1) / 2$ restrictions for $\mathrm{k}$ endogenous variables.

In order to investigate the interactions between GDP, democracy and remittances in Bangladesh we estimate two separate models in a system of stationary variables, as follows:

$$
\text { Model 1: } \quad Z_{t}=\left(G D P_{i}, D E M 1_{t}, R E M_{t}\right)
$$

Where GDP is the Gross Domestic Product in constant 2005 US dollar, DEM1 is the democracy index on the converted 0 to 1 scale based on combined average of political rights 
and civil liberty data (stationary version of democracy 1 in Figure 2) and REM is standardised personal remittances received in current US.

In order to test the robustness of the Model 1, we incorporate an alternative measure of democracy and estimate the following model:

$$
\text { Model 2: } \quad Z_{t}=\left(G D P_{i}, D E M 2_{t}, R_{E} M_{t}\right)
$$

In Model 2, GDP and REM are same as before. DEM2 is the measure of democracy index we constructed based on the principal component analysis of the political rights and civil liberty data converted to 0 to 1 scale (same as the measure democracy2 in Figure 2).

\section{Estimation and Results}

At first we check for unit roots for GDP, DEM1, DEM2 and REM. It is found that GDP is I(2), $D E M 1$ and REM are $\mathrm{I}(1)$ and DEM2 is $\mathrm{I}(0)$. These variables are then transformed in its stationary form and put into the VAR model. We select the lag length of the VAR using the information criteria and most suggested a VAR(1) model, and given that we have yearly data this is also what was expected. Having estimated the VAR(1) model, to isolate shocks to one of the VAR errors, the identification is obtained by structural factorisation, i.e., imposing restrictions on the A covariance matrix which in this paper is set as follows ${ }^{4}$ :

$$
\left[\begin{array}{ccc}
1 & a_{12} & 0 \\
0 & 1 & 0 \\
a_{31} & 0 & 1
\end{array}\right]\left[\begin{array}{c}
u_{t}^{G D P} \\
u_{t}^{D E M 1} \\
u_{t}^{R E M}
\end{array}\right]=\left[\begin{array}{ccc}
b_{11} & 0 & 0 \\
0 & b_{22} & 0 \\
0 & 0 & b_{33}
\end{array}\right]\left[\begin{array}{c}
\varepsilon_{t}^{G D P} \\
\varepsilon_{t}^{D E M 1} \\
\varepsilon_{t}^{R E M}
\end{array}\right]
$$

The non-zero coefficients $a_{12}$ and $a_{31}$ indicate the presence of contemporaneous reduced form shocks. The reason for imposing such restrictions is that it is not unreasonable to expect that democracy can affect GDP contemporaneously (see; Acemoglu et al., 2014; Papaioannou \&

\footnotetext{
${ }^{4}$ Same identification strategy used for both models.
} 
Siourounis, 2008) and that being compensatory transfers, remittances can respond to GDP of the home country in the same year (see; Chami at al., 2008, 2005; Combes \& Ebeke, 2011). $u_{t}^{G D P}, u_{t}^{D E M 1}, u_{t}^{R E M}$ correspond to the reduced form equation residuals as unexpected movements from the variables $G D P_{i}, D E M 1_{t}, R E M_{t}$ and $\varepsilon_{t}^{G D P}, \varepsilon_{t}^{D E M 1}, \varepsilon_{t}^{R E M}$ are the corresponding structural form of shocks ${ }^{5}$.

Our VAR(1) model requires $2 \mathrm{k}^{2}-\mathrm{k}(\mathrm{k}+1) / 2$ restrictions for matrix $A$ and $B$ to be just identified. We have an overidentified system with two structural restrictions imposed. In SVAR models, a shock in the system corresponds to a positive one standard deviation innovation. Figures 3-5 show upper and lower bands of impulse response function (IRF) corresponding to $\mathrm{a} \mp 2$ standard error band over 10 years.

\section{[Insert Figure 5]}

The short-run IRFs of the SVAR model1 is presented in Figure 5. The results in Figure 5 show that in case of a one-time shock of a positive one standard deviation innovation in GDP, the effect on GDP will not revert to zero even after ten periods (years), while it seems the same effect will have a transitory positive effect on democracy (DEM1). The response of remittances to the shock in GDP is not permanent, but it takes about ten periods for remittances to revert back to its original level. In case of a one-time shock of a positive one standard deviation innovation in $D E M 1$, there is a marginal non-permanent effect on $G D P$ which return to zero within five years, while the response of democracy to its own shock quickly approaches zero in less than three periods. Remittances seem almost unresponsive to any shocks to democracy. Finally, we can see that for a one-time shock of a positive one standard deviation innovation in $R E M$, the effect on GDP returns to zero after around ten periods as it does for remittances itself. The interesting result relates to how $D E M 1$ responds to a shock in $R E M$. Our results show that

\footnotetext{
${ }^{5}$ In the impulse response functions (IRF) these shocks are labelled Shock1, Shock2 and Shock3 respectively.
} 
a shock in remittances will have a negative but transitory effect on democracy. Specifically, a shock in remittances flows will lead the measure of democracy to fall at first and then rise. In all, for DEM1 to revert to zero it will take around four years. This may be explained as follows. An initial one-time shock to remittances will lead to consumption and investment shocks to the recipient households during the initial periods causing the migrant family to become less dependent on the state and further lowering their dissatisfaction with the current regime, enabling the ruling party to become relatively undemocratic. However, the effect of the initial shocks will tend to die down in successive periods, and current consumption and investment will tend to depend more on domestic economy and state patronage which will enhance the civic engagement of the migrant family members to hold the current government accountable and thereby enhancing the quality of democratic institutions. The one-time shock in remittances therefore will have negative transitory effect.

\section{[Insert Figure 6]}

In Figure 6, we present the short-run IRFs of our model2 which includes the same variable but an alternative measure of democracy (DEM2). The results are qualitatively similar to those in Figure 4 except for the response of democracy to shock in remittances. Our main concern is the response of $D E M 2$ to a one-time shock of a positive one standard deviation innovation in REM. Like before, our results show that a shock in remittances will have a negative but transitory effect on democracy with an exception. The difference here is that, after $D E M 2$ revert to zero in five years, there will be a small positive permanent effect which do not return to zero in the ten year horizon. That is the initial negative transitory effect on democracy, will be followed by very small permanent positive effect.

\section{Conclusion}


This paper adds to the expanding literature on the consequences of remittances on domestic economy and politics. The evidence in paper show that while the macro-political variables in our model help explain remittances inflow, there is an even bigger role for the converse; shocks to remittances generate sizable responses from macroeconomic and political variables. While the previous studies on this topic have examined the causal relationship between remittances and democratisation, we estimate, in departure from the literature, a SVAR model to observe the responsiveness of democracy to shocks in remittances to control for the reverse causality in these two variables by treating both as endogenous. Our results build a synergy between two opposing findings in the political science literature which suggest on one hand that remittances stabilise autocracies (Ahmed, 2012) and on the other hand that it fosters the prospect of democratisation (Escriba-Folch et al., 2015). Our data show that in the case for Bangladesh a shock in remittances will have a negative but transitory effect on democracy. That is, initially there will be a bout of autocratic episodes which will be eventually eliminated and democracy will be restored to its original level in three to five years. Using another alternative measure of democracy we also find that for a shock in remittances, there is an observed small permanent positive effect on democracy after the fifth year that do not revert to zero after the ten year period horizon. 


\section{References:}

Abdih Y., Chami, R., Dagher, J \& Montiel, P. (2012). Remittances and institutions: Are remittances a curse ? World Development, 40, 657-666.

Acemoglu, D., Naidu, S., Restrepo, P., \& Robinson, J. (2014) Democracy does cause growth, NBER Working Paper No. 20004, Cambridge, MA: National Bureau of Economic Research

Acosta, P., Lartey, E. \& Mandelman, F. (2007). Remittances and the Dutch disease. in Federal Reserve Bank of Atlanta, Atlanta.

Ahmed, F. (2012). The Perils of Unearned Foreign Income: Aid, Remittances, and Government Survival. American Political Science Review, 106 (1): 146-165.

Amuedo-Dorantes, C. \& Pozo, S. (2004). Workers' remittances and the real exchange rate: A paradox of gifts. World Development, 32, 1407-1417.

Adams, R., \& Page, J. (2005). Do international migration and remittances reduce poverty in developing countries? World Development, 33, 1645-1669.

Adams, R. J. (2005). Remittances, household expenditure and investment in Guatemala. Policy Research Working Paper Series 3532. Washington, DC: The World Bank.

Arun, T., \& Ulku, H. (2011). Determinants of remittances: The case of the South Asian community in Manchester. Journal of Development Studies, 47, 894-912.

Aslanidi, O. (2007). The Optimal Monetary Policy and the Channels of Monetary Transmission Mechanism in CIS-7 Countries - The Case of Georgia, CERGE-EI Discussion Paper No. 2 007- 1 71, January 
Barajas, A., Chami, R., Fullenkamp, C., Gapen, M., \& Montiel, P. (2009). Do workers' remittances promote economic growth? IMF Working Paper No. WP/09/153. Washington, DC: International Monetary Fund.

Barros, C., Araújo, A., \& Faria, J. (2013b). Brazilian land tenure and conflicts: The landless peasants' movement. Cato Journal 33, 47-75.

Barros, C., Faria, J., \& Araújo, A. (2013a). Brazilian land tenure conflicts: A spatial analysis. Journal of International Development, 26, 409-421.

Brandt, P., \& Freeman, J. (2009) Modeling Macro-Political Dynamics, Political Analysis $17: 113-142$

Chami, R., Hakura, D., \& Montiel, P. (2009). Remittances: An Automatic Output Stabilizer? IMF Working Paper WP/09/91. Washington, DC: International Monetary Fund.

Chami, R., Barajas, A., Cosimano, T., Fullenkamp, C., Gapen, M., \& Montiel, P. (2008). Macroeconomic Consequences of Remittances Occasional Paper No. 259. Washington, DC: International Monetary Fund.

Chami, R., Fullenkamp, C., \& Jahjah, S. (2003). Are immigrant remittance flows a source of capital for development? IMF Working Paper WP/03/189. Washington, DC: International Monetary Fund.

Chami, R., Fullenkamp, C., \& Jahjah, S. (2005). Are immigrant remittance flows a source of capital for development. IMF Staff Papers, 52, 55-81.

Chiodi, V., Jaimovich, E., \& Montes-Rojas, G. (2012). Migration, remittances and capital accumulation: Evidence from rural Mexico. Journal of Development Studies 48, $1139-1155$. 
Combes, J., \& Ebeke, C. (2011). Remittances and household consumption instability in developing countries. World Development, 39, 1076-1089.

Cox Edwards, A., \& Ureta, M. (2003). International migration, remittances and schooling: Evidence from El Salvador. Journal of Development Economics, 72, 429-461.

Escriba-Folch, A., \& Meseguer, C. (2015) Remittances and Democratisation, International Studies Quarterly, online (doi: $\underline{10.1111 / \text { isqu.12180) }}$

Frank, R., \& Hummer, R. (2002). The other side of the paradox: The risk of low birth weight among infants of migrant and nonmigrant households within Mexico. International Migration Review, 36, 746-765.

Gastil, R. (1982-1987) Freedom in the World. Westport, Conn.: Greenwood, various years.

Gianni, A., \& Giannini, C. (1997). Topics in Structural VAR Econometrics, 2nd Ed., Berlin: Springer-Verlag

Gupta, S., Pattillo, C., \& Wagh, S. (2009). Effect of remittances on poverty and financial development in Sub-Saharan Africa. World Development, 37(1), 104-115.

Hanson, G., \& Woodruff, C. (2003). Emigration and Education Attainment in Mexico. mimeo. University of California, San Diego. Retrieved from: http://irps.ucsd.edu/assets/022/8772.pdf

Hassan, G. \& Holmes, M. (2013). Remittances and the real effective exchange rate. Applied Economics, 45, 4959-4970. 
Hildebrant, N., \& McKenzie, D. (2005). The effect of migration on child health in Mexico World Bank Policy Research Working Paper 3573 and Department of Economics, Stanford University. Washington, DC: The World Bank.

Kapur, D. (2010) Diaspora, Development and Democracy. The Domestic Impact of International Migration From India. Princeton, New Jersey: Princeton University Press.

Kurosaki, T. (2006). Consumption vulnerability to risk in rural Pakistan. Journal of Development Studies, 42(1), 70-89.

Lewis, D. (2011) Bangladesh Politics, Economy and Civil Society, Cambridge: Cambridge University Press

Mishra, P. (2005). Macroeconomic impact of remittances in the Caribbean. Unpublished paper. Washington, DC: International Monetary Fund.

Montiel, P. (1999). Determinants of the long-run equilibrium exchange rate: An analytical model. In L. Hinkle and P. Montiel (Eds.), Exchange Rate Misalignment: Concepts and Measurement for Developing Countries. Oxford: Oxford University Press.

Meseguer, C., \& Burgess, K. (2014) International Migration and Home Country Politics. Studies in Comparative International Development, 49 (1): 1-12.

Morrison, K. (2009) Oil, Non-Tax Revenue, and the Redistributional Foundations of Regime Stability. International Organization, 63 (1): 107-138.

Moses, J. (2011) Emigration and Political Development. New York: Cambridge University Press. 
Page, J., \& Plaza, S. (2006). Migration remittances and development: A review of global evidence. Journal of African Economies, 15, 245-336.

Papaioannou, E., \& Siourounis, G. (2008). Democratisation and Growth, Economic Journal, $118(532), 1520-1551$.

Pfutze, T. (2012). Does Migration Promote Democratization? Evidence from the Mexican Transition. Journal of Comparative Economics 40(2):159-175.

Pfutze, T. (2014) Clientelism vs. Social Learning: The Electoral Effects of International Migration. International Studies Quarterly, 58(2): 295-307.

Quartey, P., \& Blankson, T. (2004). Do migrant remittances minimize the impact of macrovolatility on the poor in Ghana? Report prepared for the Global Development Network (GDN). Washington. DC: International Monetary Fund.

Ratha, D. (2009). Leveraging remittances for development. Migration Policy Institute Policy Brief No. 3, June 2007. Washington DC: Migration Policy Institute.

Regan, P., \& Frank, R. (2014) Migrant Remittances and the Onset of Civil War. Conflict Management and Peace Science, 31 (5): 502-520.

Sayan, S. (2006). Business cycles and workers' remittances: How do migrant workers respond to cyclical movements of GDP at home? IMF Working Paper No. WP/06/52. Washington, DC: International Monetary Fund.

Weiss, A. (2014) The Domestic Politics of South Asia, Bowman \& Littlefield 
World Bank. (2006). The development impact of workers' remittances in Latin America. Vol. 2: Detailed Findings (Chapter 3, Section V). Report No. 37026. Washington, DC: World Bank.

Yang, D., \& Choi, H. (2007). Are remittances insurance? Evidence from rainfall shocks in the Philippines. World Bank Economic Review 21, 219-248. 
Figure 1. Remittances in Bangladesh 1976-2012

Personal Remittances Received in USD

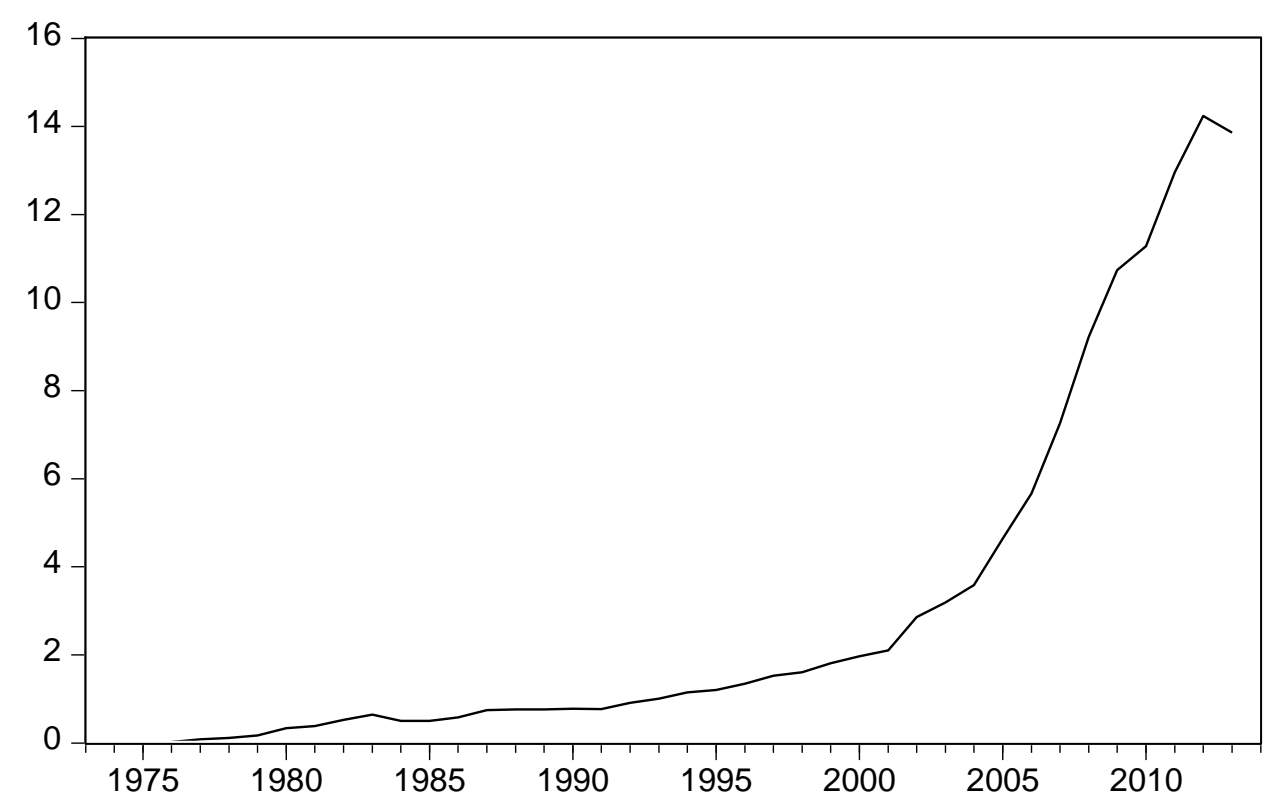

Figure 2. Remittances Growth in Bangladesh 1976-2012

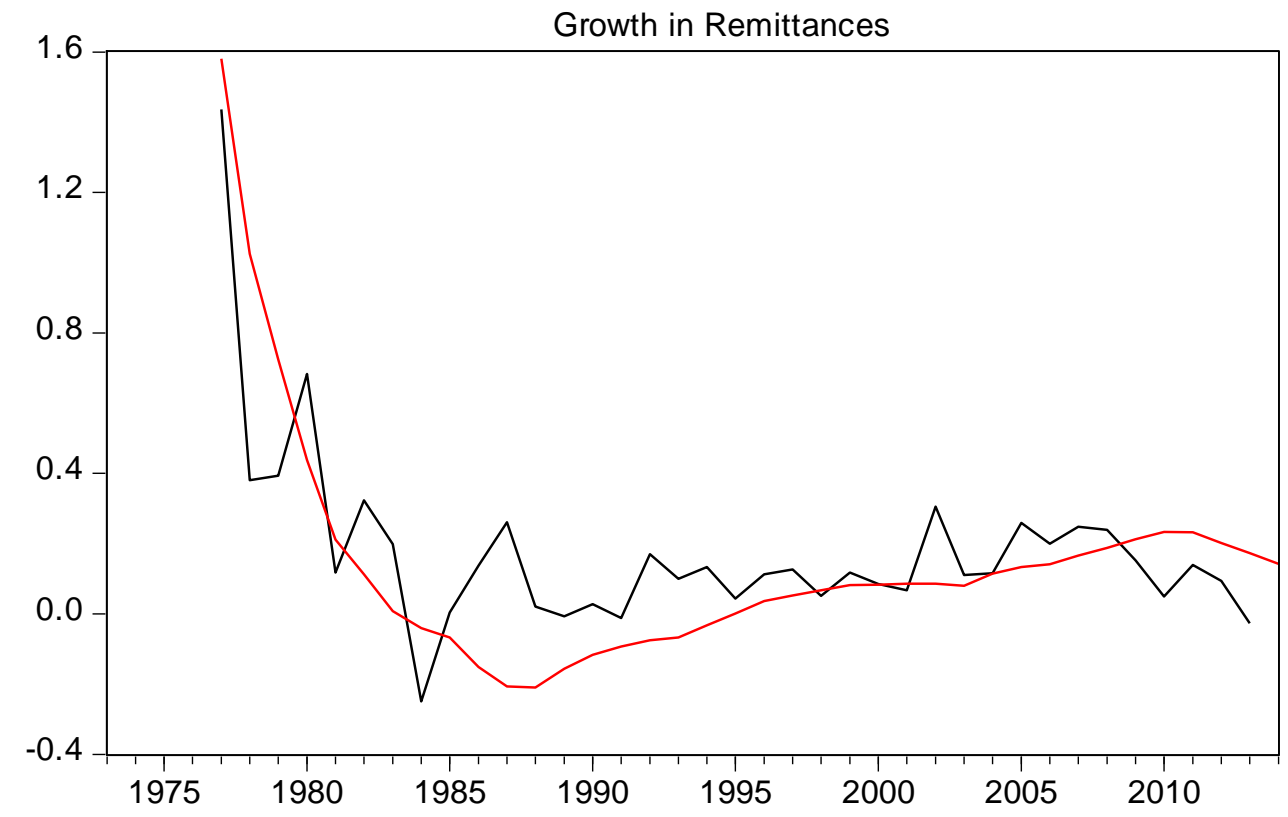


Figure 3. Political Rights and Civil Liberty in Bangladesh: 1973 - 2012.

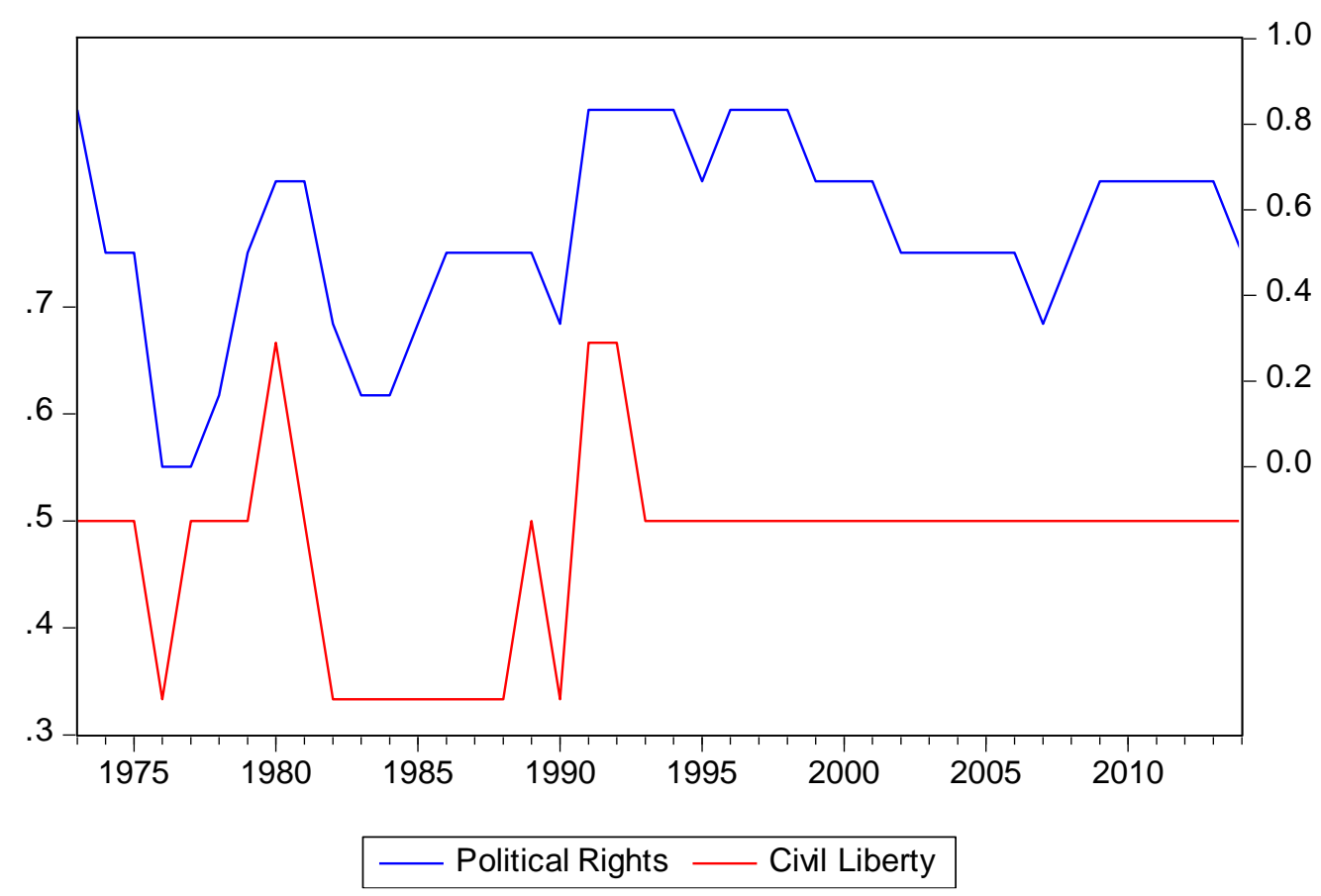

Figure 4. Democratisation Process in Bangladesh: 1973 - 2012

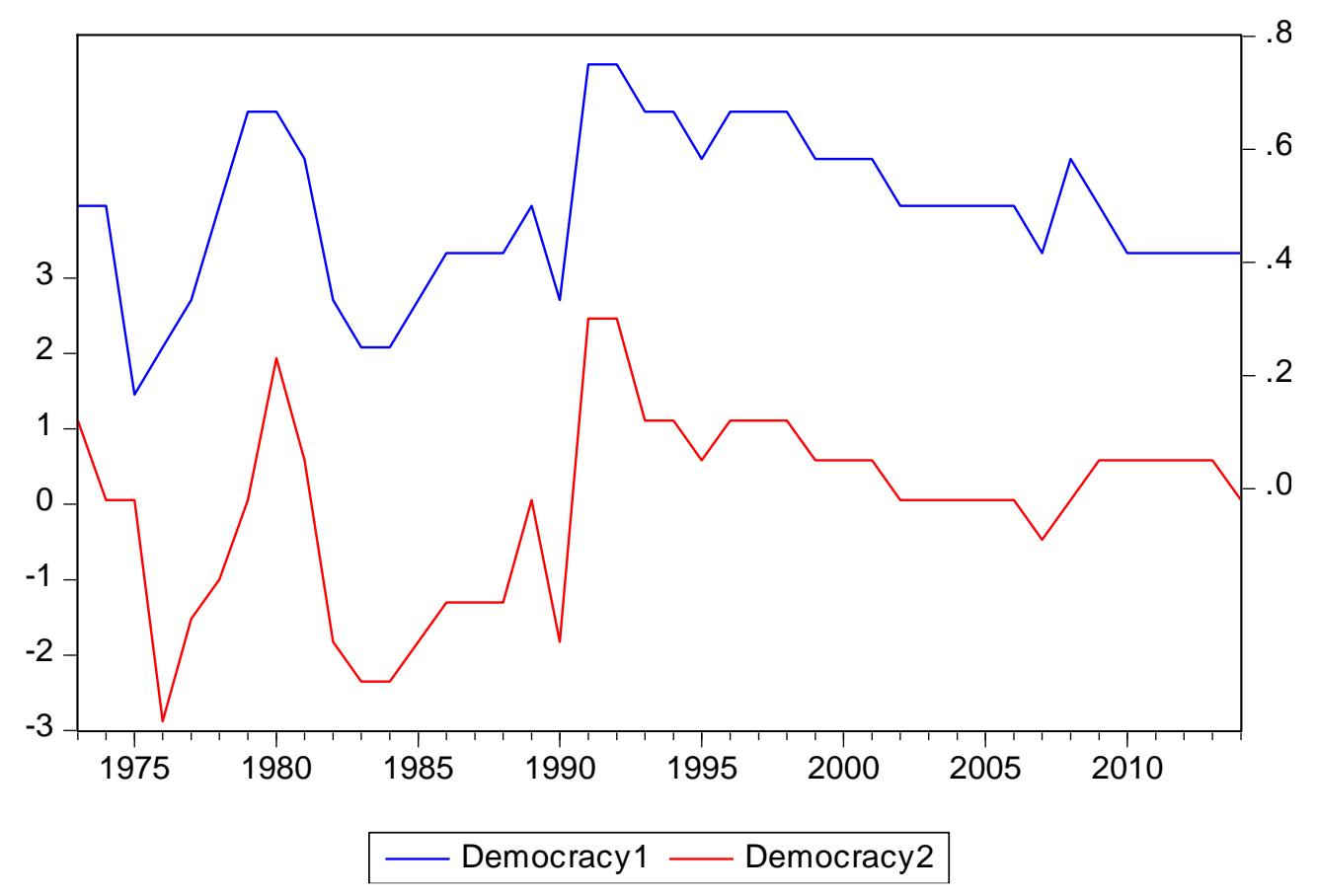




\section{Figure 5. Impulse Response Functions from Model1}

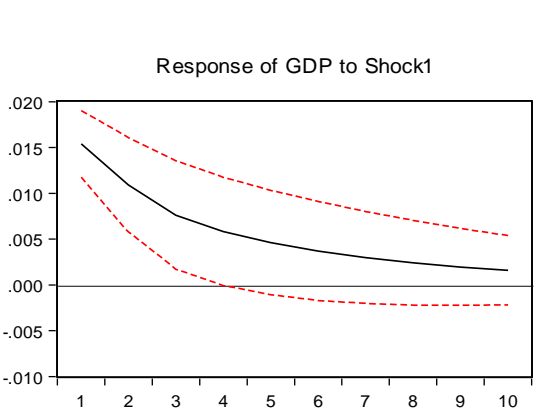

MODEL1: Response to Structural One S.D. Innovations \pm 2 S.E.
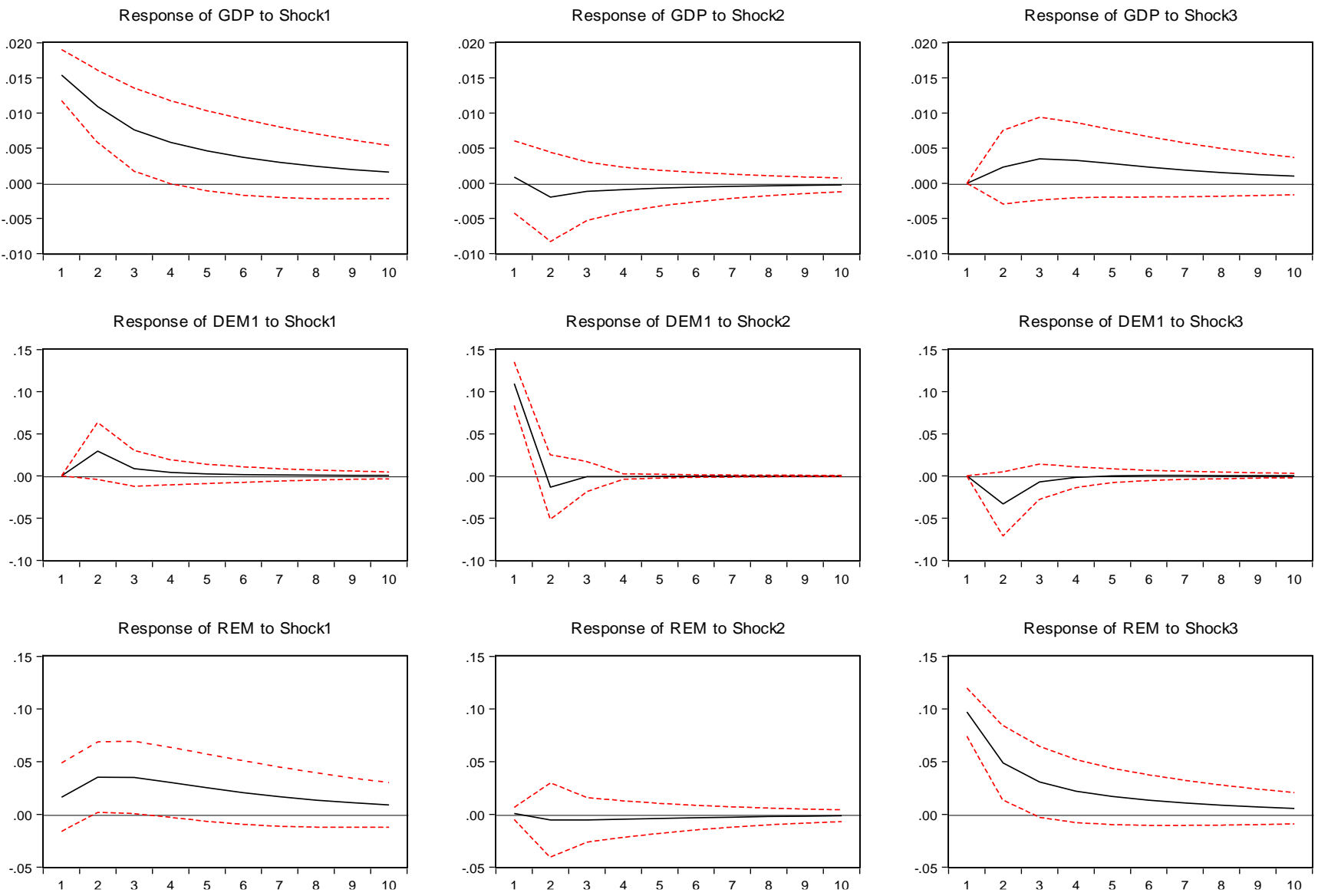


\section{Figure 6. Impulse Response Functions from Model2}

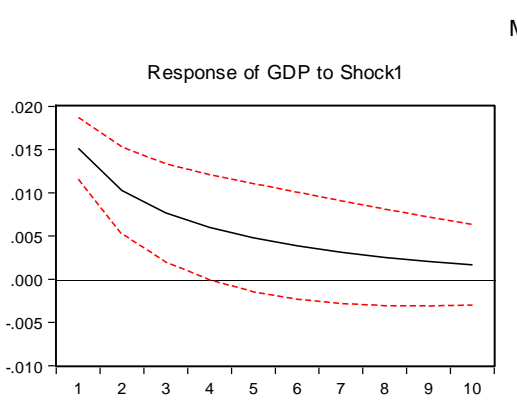

MODEL2: Response to Structural One S.D. Innovations \pm 2 S.E.
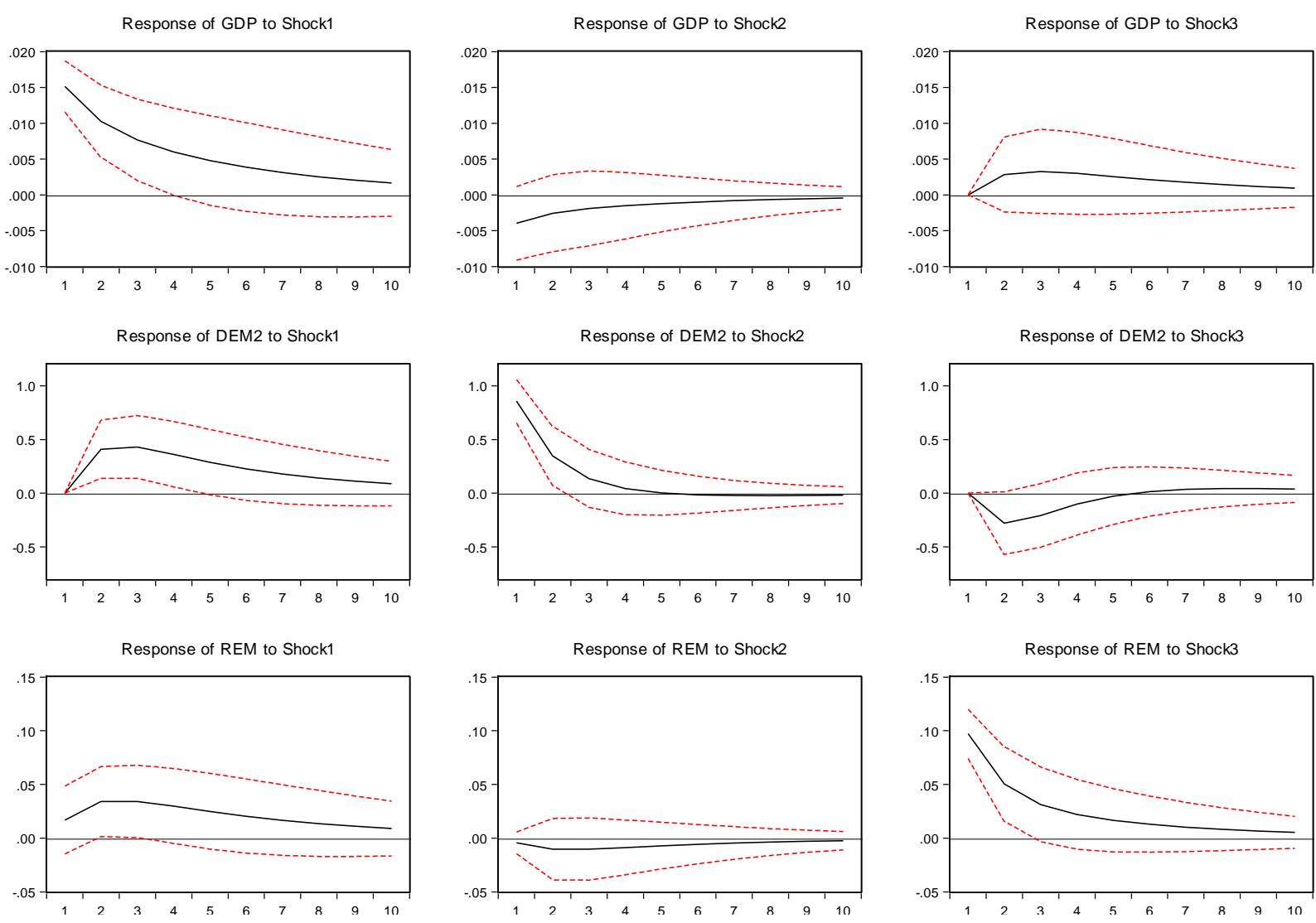